\title{
A comparison of the effect of chlorhexidine and collagen cross-linking agent (oak extract) used for different times on composite-dentine micro tensile bond strength
}

\author{
Porównanie wpływu chlorheksydyny i czynnika sieciującego kolagenu \\ (ekstraktu z dębu) zastosowanych przez różny okres na wytrzymałość \\ wiązania materiału kompozytowego z zębiną na mikrorozciąganie
}

\author{
Roghayeh Ghasemi¹, Mehran Mapar², Faramarz Zakavi² \\ ${ }^{1}$ Department of Restorative Dentistry, School of Dentistry, Bushehr University of Medical Sciences, Bushehr, Iran \\ ${ }^{2}$ Department of Restorative Dentistry, School of Dentistry, Ahvaz Jundishapur University of Medical Sciences, Ahvaz, Iran
}

Medical Studies/Studia Medyczne 2021; 37 (2): 125-130

DOI: https://doi.org/10.5114/ms.2021.107456

Key words: chlorhexidine, collagen, oak extract, composite-dentine.

Słowa kluczowe: chlorheksydyna, kolagen, ekstrakt z dębu, wiązanie materiału kompozytowego z zębiną.

\begin{abstract}
Introduction: The chief goal of restorative dentistry is to provide resin-dentin bond strength. Several materials have been proposed to strengthen the bond. External cross-link factors are a group of materials that improve the collagenic cross-links. Proanthocyanidins are a class of polyphenols found in a variety of plants including oak.

Aim of the research: To compare the effect of chlorhexidine and collagen cross-linking agent (oak extract) used for different times on composite-dentine micro tensile.

Material and methods: In the in vitro study, oak fruit was collected and used to make 33\% oak extract. After that, 14 molar teeth were used, enamel was removed, and dentin was exposed. Then, 5 different protocols were used to prepare the teeth: 1. Using oak extract for $90 \mathrm{~s}, 2$. Using oak extract for $180 \mathrm{~s}$, 3. Using oak extract and chlorhexidine for $90 \mathrm{~s}, 4$. Using oak extract and chlorhexidine for $180 \mathrm{~s}$, and 5. Control group. Finally, the bonding strength was compared between the groups.

Results: The maximum and minimum of bond strength were found in control and group 1 (24.86 vs. 19.49), respectively. All 4 intervention groups showed significant lower bonding strength than did the controls. The level of significance was lower than 0.0001 . The least mean differences with controls (4.75) were seen in group 4.

Conclusions: Our findings indicated that treatment with oak extract led to a decrease of the resin-dentin bond strength.
\end{abstract}

\section{Streszczenie}

Wprowadzenie: Głównym celem stomatologii odtwórczej jest zapewnienie wytrzymałości wiązania żywicy z zębiną. W celu wzmocnienia tego wiązania zaproponowano kilka materiałów. Zewnętrzne czynniki sieciujące to grupa materiałów, które poprawiają wiązania kolagenowe. Proantocyjanidyny to klasa polifenoli występujących w różnych roślinach, w tym w dębie.

Cel pracy: Porównanie wpływu chlorheksydyny i czynnika sieciującego kolagenu (ekstraktu z dębu) zastosowanych przez różny czas na wytrzymałość wiązania materiału kompozytowego z zębiną na mikrorozciąganie.

Materiał i metody: W badaniu in vitro zebrano owoce dębu i przygotowano z nich 33-procentowy ekstrakt. Następnie z 14 zębów trzonowych usunięto szkliwo i odsłonięta została zębina. Zastosowano 5 różnych protokołów do przygotowania zębów: 1) zastosowanie ekstraktu z dębu przez 90 s, 2) zastosowanie ekstraktu z dębu przez 180 s, 3) zastosowanie ekstraktu z dębu oraz chlorheksydyny przez $90 \mathrm{~s}$, 4) zastosowanie ekstraktu z dębu oraz chlorheksydyny przez $180 \mathrm{~s}$ oraz 5) grupa kontrolna. Na koniec porównano wytrzymałości wiązania pomiędzy grupami.

Wyniki: Maksymalną i minimalną wytrzymałość wiązania stwierdzono w grupie kontrolnej i grupie 1 (odpowiednio 24,86 vs 19,49). We wszystkich 4 grupach badanych wykazano istotnie niższą wytrzymałość wiązania niż w grupie kontrolnej. Poziom istotności wynosił poniżej 0,0001. Najmniejsze średnie różnice w stosunku do grupy kontrolnej $(4,75)$ zaobserwowano w grupie 4.

Wnioski: Nasze badanie wykazało, że leczenie z zastosowaniem ekstraktu z dębu przyniosło zmniejszenie wytrzymałości wiązania żywicy z zębiną. 


\section{Introduction}

Having access to a strong bond in resin composite and dentin has been a basic argument in adhesive dentistry [1]. Using an external cross-link can lead to the formation of more collagen cross-links [2]. Marginal seal loss and reduction of strength of connective restorations affect the restoration life span in enamel and dentin [3]. Clinical studies have shown that the resindentin bond is not durable, and constant damage of this bond causes failure of adhesive restorations $[4,5]$. The adhesive-dentin gap might be porous and acts as an impenetrable membrane, so collagen fibril type 1 exposed in hybrid layer depth might be destroyed due to eluted monomers [6], water absorption, polymer inflammation, and resin hydrolase [7-9]. Destruction of exposed collagen in the dentin hybrid layer is the main mechanism in the instability of the resin-dentin bond strength [10, 11]. Chlorhexidine (CHX) has widely been used as an anti-microbial factor and has many activities against oral bacteria [12]. CHX can also act as a potential inhibitor for matrix metalloproteinase and plays a role in long-term stability of the hybrid layer and resin-dentin bond strength [13]. Many cross-link factors have been studied including glutardialdehyde and proanthocyanidin as stabilizer factors in collagen fibrils [14-16]. The first successful attempt at adhesive dentistry was provided in 1955 when Bonoker introduced phosphoric acid to create gear micromechanical by resin tags in enamel [17]. Resin material bonding to dentin creates a problem due to the complexity of the dentin structure derived from its superficial moisture and collagen network [18]. Generally, etching acid in etch-and-rinse systems demineralizes the dentin surface to a few microns thickness and exposes the collagen network to penetration of resin into them. Wet dentin relatively improves resin-dentin strength because the water maintains porous of collagen network which are available for distribution and penetration of monomers. If the dentin surface is dried with air, the collagen rapidly experiences collapse and prevents resin monomers [19]. After aging, resin-dentin strength in adhesives with different generations is reduced. In order to cope with the instability of the resin-dentin bond, researchers indicated that $\mathrm{CHX}$ plays an important role in increasing this bond [20].

Different cross-link factors have been studied so far, including aldehyde [21], acyl azide [22], and proanthocyanidin [14]. Furthermore, aromatic combinations in plants such as tannins, and flavonoids contain hydroxyl units and have the capacity of bonding with proteins [23]. It should be mentioned that tannins have high hydroxyl groups, and this factor exists in different groups such as oak [24, 25].

\section{Aim of the research}

Considering the effect of cross-link factors in improving the composite bond to target dentin, the aim of the present study was to investigate the effect of $\mathrm{CHX}$ as an inhibitor factor of MMPs and oak extraction as external cross-link factor without irrigation, used for different times, on the strength of adhesive system bonds.

\section{Material and methods}

This study was performed in in vitro conditions and data were collected by observation technique and using the bond micro tensile strength test. The study population included 14 healthy molar human teeth, of which an average 5 teeth were obtained, and after removing enamel and superficial dentin the surfaces of all teeth were etched and prepared by the following methods:

1) Using oak extract,

2) Using chlorhexidine and oak extract,

3) No materials were used except irrigation of etching factor.

The surfaces of the samples were filled with composite after adhesion, using aluminium cylinders with $5 \mathrm{~mm}$ height, and they were trimmed to perform a micro tensile test using universal testing (Doli EDC-580, Germany). The strength of the bond composite to the samples was determined and reported, accordingly. In this study, 14 healthy human molar teeth were collected, and debris and tissues were removed from their surface by scaler (Guilin Woodpecker Medical Instrument Co, Ltd, DTE D5, China), and they were submerged in $0.5 \%$ aqueous thymol solution. The occlusal surface of teeth was removed from its surface in order to reach the dentin using a trimmer (Dentau Rum P.O.B.440, Germany). Then, by using a 600-grit carbide silicon polisher (Matador Softlex 991A, Germany) and a water cooler for $30 \mathrm{~s}$, a smear layer was created on the trimmed occlusal surface.

In the next step, the prepared dentin surface was etched in all samples with $37 \%$ phosphoric acid gel (Pulpdent, USA) for $15 \mathrm{~s}$ and then irrigated by water for $10 \mathrm{~s}$. Any additional moisture was removed from the surface by dry wad. The samples were divided into 5 groups. Then, the surfaces were prepared using the following steps:

- Group 1: oak extract with $33.3 \mathrm{mg} / \mathrm{ml}$ density was performed on dentin for $90 \mathrm{~s}$.

- Groups 2: oak extract with $33.3 \mathrm{mg} / \mathrm{ml}$ density was performed on dentin for $180 \mathrm{~s}$.

- Group 3: first, chlorhexidine 2\% (CHX) (Ultradent product, USA) was performed on the dentin for $30 \mathrm{~s}$, and then oak extract was performed on the surface for $90 \mathrm{~s}$, and the excess was removed by dry wad.

- Group 4: first, chlorhexidine 2\% (CHX) (Ultradent product, USA) was performed on the dentin for $30 \mathrm{~s}$, and then oak extract was performed on the surface for $180 \mathrm{~s}$, and the excess was removed by dry wad.

- Group 5: no surface preparation was performed after etching. 
After surface preparation of each group, Adper Single Bond 2 (3M ESPE; St Paul, MN, USA) was performed based on the manufacturer's instructions and was light-cured with an LED curing unit (Bonart, ART-L3, Xinzhuang District, New Taipei City, Taiwan) with $470 \mathrm{mw} / \mathrm{cm}^{2}$ light intensity. The intensity of the curing light was checked after the end of light curing using light an intensity meter which was available on the unit.

Then a light cure composite (Filtek TM Z250, 3M ESPE, USA) was placed on the surface in $5 \mathrm{~mm}$ thickness (first layer, then next layer with $2 \mathrm{~mm}$ thickness), and it was light cured based on the manufacturer's instructions for $20 \mathrm{~s}$.

In order to provide a tape with which we could compress the composite on the teeth, the ends of the temporary covers were cut (Shadi Dental Co, Iran) and placed around the tooth in tape form.

All samples were placed in distilled water and kept in an incubator $\left(37^{\circ} \mathrm{C}\right)$ (Incubator IN30, Memmert, Germany) for 3 months. The teeth were mounted by cylinder moulds in autopolymerizing acrylic resin (Acropars, Marlic Co., Tehran, Iran). Then, they were trimmed using a trimming machine (Macatum T201T210, Co persy French) to obtain samples with dimensions of $1 \times 1 \mathrm{~mm}$.

After 3-month storage, all samples were thermocycled for 5000 cycles $\left(5-55^{\circ} \mathrm{C}\right)$ in a bath of water for $20 \mathrm{~s}$ and $15 \mathrm{~s}$ for displacement time using a thermocycler (Analytik Jena AG, Germany). Following thermocycling $\left(5000\right.$ cycles, $\left.5-55^{\circ} \mathrm{C}\right)$, the specimens were tested for tensile strength at $5 \mathrm{~mm} / \mathrm{min}$ until breakage on a universal testing machine (Doli, EDC 580, Germany). Data were recorded automatically. Further stress-strain data were captured and saved.

\section{Ethical consideration}

The present study was conducted with the approval of the ethical committee of Ahvaz Jundishapur University of Medical Sciences, Ahvaz, Iran (Registration No: IR.AJUMS.REC. 1396.388).

\section{Statistical analysis}

Data were analysed using one-way ANOVA, Kruskal-Wallis test, Tukey test, and SPSS version 23 (SPSS Inc., Chicago, Ill., USA). $P$-value less than 0.05 (typically $\leq 0.05$ ) was considered statistically significant.

\section{Results}

Table 1 represents a summary of the descriptive statistics, including mean, median, standard deviation, and 95\% confidence level for mean. Based on these results, the highest and lowest levels of microtensile bond strength were related to the control group and oak, respectively, at $90 \mathrm{~s}$ after treatment (24.86 against 19.49).

In the next step, in order to analyse the data, the D'Agostino-Pearson omnibus normality test was utilized. Based on this test, the null hypothesis followed a normal distribution. Accordingly, if $p$ is higher than 0.05 , data distribution is normal. Thus, all the studied groups followed the normal distribution. Parametric tests were used to analyse the data (Table 2).

After proving the normality of data for studying micro-tensile bond strength in different groups, Tukey's multiple comparison was used. First, 4 groups were compared with the control group, and it was understood that the 4 groups had less micro-tensile bond

Table 1. Descriptive analysis of survey data

\begin{tabular}{|lccccc|}
\hline Parameter & Mean & Median & Std. deviation & Lower 95\% Cl of mean & Upper 95\% Cl of mean \\
Control $(n=8)$ & 24.86 & 24.47 & 2.154 & 23.06 & 26.66 \\
OAK $90(n=8)$ & 19.49 & 19.22 & 1.344 & 18.37 & 20.61 \\
OAK $180(n=8)$ & 20 & 19.35 & 2.121 & 18.22 & 21.77 \\
CHX-OAK180 $(n=8)$ & 20.1 & 19.67 & 2.13 & 18.32 & 21.88 \\
CHX-OAK90 $(n=8)$ & 20.03 & 19.54 & 2.959 & 17.56 & 22.51 \\
\hline
\end{tabular}

Table 2. D'Agostino-Pearson omnibus test

\begin{tabular}{|lcccc|}
\hline Parameter & K2 & $P$-value & Passed normality test $(\alpha=0.05) ?$ & $P$-value summary \\
Control $(n=8)$ & 0.373 & 0.8299 & Yes & NS \\
OAK $90(n=8)$ & 1.947 & 0.3777 & Yes & NS \\
OAK $180(n=8)$ & 2.318 & 0.3139 & Yes & NS \\
CHX-OAK180 $(n=8)$ & 10.27 & 0.059 & Yes & NS \\
CHX-OAK90 $(n=8)$ & 1.048 & 0.5922 & Yes & NS \\
\hline
\end{tabular}


Table 3. Comparison of adhesive bond strength in the studied groups compared to control group

\begin{tabular}{|lccccc|}
\hline Test details & Mean 1 & Mean 2 & Mean diff. & SE of diff. & Significance \\
Control vs. OAK 90 & 24.86 & 19.49 & 5.367 & 1.101 & $* * *$ \\
Control vs. OAK 180 & 24.86 & 20.00 & 4.862 & 1.101 & $* * *$ \\
Control vs. CHX-OAK180 & 24.86 & 20.10 & 4.756 & 1.101 & $* *$ \\
Control vs. CHX-OAK90 & 24.86 & 20.03 & 4.825 & 1.101 & $* * *$ \\
\hline
\end{tabular}

Table 4. Comparison of adhesive bond strength in the studied groups

\begin{tabular}{|lccccc|}
\hline Test details & Mean 1 & Mean 2 & Mean diff. & SE of diff. & Significance \\
OAK 90 vs. OAK 180 & 19.49 & 20.00 & -0.5049 & 1.101 & NS \\
OAK 90 vs. CHX-OAK180 & 19.49 & 20.10 & -0.6113 & 1.101 & NS \\
OAK 90 vs. CHX-OAK90 & 19.49 & 20.03 & -0.5428 & 1.101 & NS \\
OAK 180 vs. CHX-OAK180 & 20.00 & 20.10 & -0.1064 & 1.101 & NS \\
OAK 180 vs. CHX-OAK90 & 20.00 & 20.03 & -0.03789 & 1.101 & NS \\
CHX-OAK180 vs. CHX-OAK90 & 20.10 & 20.03 & 0.06850 & 1.101 & NS \\
\hline
\end{tabular}

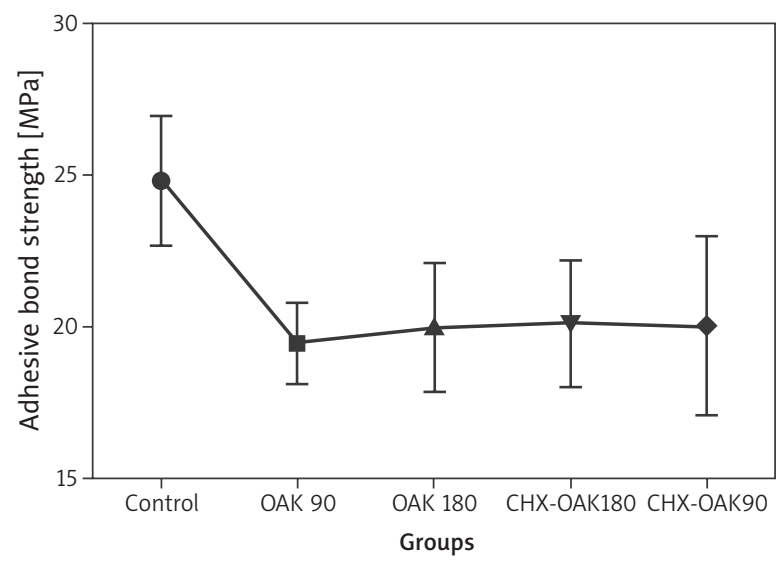

Figure 1. Comparison of adhesive bond strength in the studied groups

strength than the control group. This difference was statistically significant at the 0.001 level $\left({ }^{* * *}\right)$. The least mean difference (4.75) in comparing control groups with others was related to comparing the control and using chlorhexidine and oak extract at the time point of $180 \mathrm{~s}$ (Control vs. OAK 180). A summary of the results is provided in Tables 3 and 4 and Figure 1.

\section{Discussion}

One of the main issues in adhesive dentistry is creating a strong bond between resin and dentin, which is achievable by increasing collagen cross-links with external cross-linking agents. In fact, this strong connection increases the restoration lifespan by preventing damage of the marginal seal and reducing the connective restorative bond strength $[1,2]$. Thus, finding appropriate cross-link factors is the main field of research in restorative dentistry. Various crosslinking agents including natural materials and synthetics have been recommended by several studies [15]. Natural cross-linking agents, which are naturally derived from plant extracts, reduce cytotoxicity compared to synthetic agents, so they can be appropriate replacements for synthetic materials [15].

Oak extract has been used in different biological conditions including tissue restoration. Heydari et al. studied the pharmaceutical properties of tannin, which is available in oak powder, for wound healing and skin repair of rats [26]. Similarly, Yumachigi et al. examined the restorative characteristics of oak extract for promoting wound healing in rats and confirmed the role of oak extract on the restoration process and tissue formation [27]. Oak extract is effective on the production and structure of collagens through its tannin. Hemmati et al. illustrated that oak extract significantly increases collagen synthesis [27]. One of the most effective factors in creating a strong bond between resin and dentin composite is the collagen content of dentin. So, oak extract can reinforce the bond between the resin and the dentin composite [28].

The results of the present study illustrate that 90 -second and 180 -second treatments of dentin by oak extract not only increased the micro tensile strength of the bond rather than the control group but also reduced it significantly. In contrast to this study, Mapar et al. indicated that oak extract increases the micro tensile strength of the bond more than in the control group, although this difference was not significant [28]. In a study by Mapar et al. treatment with oak extract lasted $30 \mathrm{~s}$, while in this study the treatment lasted for 90 and $180 \mathrm{~s}$. So, the increase of treatment time is along with reduction of oak extract effect. In addition, in the 
Mapar study, oak extract was irrigated after a certain time duration and then drying was performed, while in this study the oak extract was dried without irrigation and only by low pressure air. In order to attain an efficient outcome, material such as collagen is not washed during treatment, so in this study oak extract was not washed, accordingly. This might be explained by the hydrophilic properties of oak extract, i.e. when oak extract is not irrigated, it prevents the collagen network from collapsing (prevents hydrophobic resin penetration into collagen network bonding). Another reason may be the physical presence of oak extract in the collagen network exposed to acid, which prevents penetration and occupies bonding space.

In addition, as was stated, the incremental effect of oak extract on the micro-tensile strength of the bond is due to the tannin content of oak extract. It was recorded that the tannin content of oak extract varies by season, climate, and subspecies [29]. Hence, another reason for the different findings in this study and the study by Mapar et al. might be the different tannin content applied in oak extract. Castellan et al. also studied the effectiveness of cross-link extract. They indicated that teeth treatment with these materials increased the connective strength of teeth and resin significantly [30]. In this study, the duration of treatment was totally different: $60 \mathrm{~min}$ and $10 \mathrm{~min}$ of proanthocyanidin had a significant effect on the strength rate. Finally, in this study it was illustrated that proanthocyanidin in different plant extracts has different structures, and hence has different effectiveness [30]. Based on previous studies, $\mathrm{CHX}$ has positive effects on the micro-tensile strength of the bond. The results of this study showed that adding chlorhexidine $(\mathrm{CHX})$ to oak extract enhanced the micro-tensile strength of the bond. This is in line with the results of previous studies. Leitane et al. in 2011 in Brazil studied the effect of chlorhexidine on adhesive bond strength. The results showed that using $2 \% \mathrm{CHX}$ for $30 \mathrm{~s}$ after etching acid is effective on the immediate and long-term bond strength of adhesive in baby teeth [31]. In addition, Loguercio et al. illustrated that using $0.002 \%$ chlorhexidine for $15 \mathrm{~s}$ is effective in increasing the bond strength [32]. The limitation of this study was that the CHX was not measured, so we could not accurately analyse the effectiveness of this material on the micro-tensile strength of the bond.

Although the effectiveness of oak materials has not been fully identified, evidence has shown that the cross-link effect of collagen is probably related to tannins [33]. Various studies have shown the effect of these proanthocyanidin tannins on increasing microtensile strength. Liu et al. examined the capability of proanthocyanidin in improving the biologic characteristics of dentin collagen through creating a crosslink for different times. They concluded that using proanthocyanidin for $10 \mathrm{~s}$ increases dentin resistance against collagenase, and spectroscopy studies showed that proanthocyanidin increases collagen uniformi- ty [34]. In addition, Srinivasulu et al. in an experimental study evaluated the composite shear bond strength to deep dentin after using 2 collagen cross-links (10\% sodium ascorbic and $6.5 \%$ proanthocyanidin). The results indicated that using cross link factors increases the shear bond strength to deep dentin more than in the control group. In samples with proanthocyanidin the shear bond strength was significantly higher than samples with ascorbic acid [35].

Also, Leme-Krause et al. a study on the biostability of proanthocyanidin in adhesion showed that this material increases cohesion to tissues enriched with type 1 collage through a new mechanism which is not dependent upon hydrophilic monomers. This mechanism involves chemical physical changes of the tooth matrix, reduction of environmental damage, and creating a pole in methyl acrylate [36]. So, the evidence approves the important role of anthocyanidins in improving micro-tensile bond strength. Thus, selecting good oak for extraction with the highest level of anthocyanidin can have a better effect. In addition, by methods of organic materials analysis, this material can be effective in evaluating the micro-tensile bond strength. According to the Mapar et al. study, oak extract needs to be washed from dentin after its usage.

\section{Conclusions}

Generally, the results of this study showed that the maximum and minimum bond strengths were found in the control group and group 1 (24.86 vs. 19.49), respectively. All 4 intervention groups showed significantly lower bonding strength than that of the control group. Furthermore, the level of significance was lower than 0.0001 . The least mean differences with control (4.75) were observed in group 4 . It can be concluded that treatment with the oak extract leads to a decrease in the resin-dentin binding strength.

\section{Acknowledgments}

This paper was extracted as a part of Roghayeh Ghasemi's thesis. The study was financially supported by research affairs of Ahvaz Jundishapur University of Medical Sciences (Grant No. u96068).

\section{Conflict of interest}

The authors declare no conflict of interest.

\section{References}

1. Mehran M, Faramarz Z, Nematolah FA, Fatemeh RS, Amir S. The comparison of effect of chlorhexidine and proanthocyanidin and grape seed extract on compositedentin micro tensile bond strength: an in vitro experimental study. Jundishapur Sci Med J 2016; 15: 283-293.

2. Yamauchi M. Collagen biochemistry: an overview. In: Advances in Tissue Banking Philips GO (ed). World Scientific 2002; 445-500. 
3. Monticelli F, Toledano M, Silva AS, Osorio E, Osorio R. Sealing effectiveness of etch-and-rinse vs self-etching adhesives after water aging: influence of acid etching and $\mathrm{NaOCl}$ dentin pretreatment. J Adh Dentistry 2008; 10: 183-188.

4. De Munck J, Van Meerbeek B, Yoshida Y, Inoue S, Vargas M, Suzuki K, Lambrechts P, Vanherle G. Four-year water degradation of total-etch adhesives bonded to dentin. J Dental Res 2003; 82: 136-140.

5. Hashimoto M, Fujita S, Endo K, Ohno H. In vitro degradation of resin-dentin bonds with one-bottle self-etching adhesives. Eur J Oral Sci 2009; 117: 611-617.

6. Hashimoto M, Ohno H, Sano H, Kaga M, Oguchi H. In vitro degradation of resin-dentin bonds analyzed by $\mathrm{mi}$ crotensile bond test, scanning and transmission electron microscopy. Biomaterials 2003; 24: 3795-3803.

7. van Dijken JW, Sunnegårdh-Grönberg K, Lindberg A. Clinical long-term retention of etch-and-rinse and self-etch adhesive systems in non-carious cervical lesions: a 13 years evaluation. Dental Materials 2007; 23: 1101-1107.

8. Tay FR, Pashley DH, Suh BI, Carvalho RM, Itthagarun A. Single-step adhesives are permeable membranes. J Dent 2002; 30: 371-382.

9. Pashley DH, Tay FR, Yiu C, Hashimoto M, Breschi L, Carvalho RM, Ito $\mathrm{S}$. Collagen degradation by host-derived enzymes during aging. J Dent Res 2004; 83: 216-221.

10. Donmez N, Belli S, Pashley DH, Tay FR. Ultrastructural correlates of in vivo/in vitro bond degradation in selfetch adhesives. J Dent Res 2005; 84: 355-359.

11. Liu Y, Tjäderhane L, Breschi L, Mazzoni A, Li N, Mao J, Pashley DH, Tay FR. Limitations in bonding to dentin and experimental strategies to prevent bond degradation. J Dent Res 2011; 90: 953-968.

12. Stanley A, Wilson M, Newman $\mathrm{H}$. The in vitro effects of chlorhexidine on subgingival plaque bacteria. J Clin Periodontol 1989; 16: 259-264.

13. Gendron R, Grenier D, Sorsa T, Mayrand D. Inhibition of the activities of matrix metalloproteinases 2,8 , and 9 by chlorhexidine. Clin Diagn Lab Immunol 1999; 6: 437-439.

14. Bedran-Russo AKB, Pereira PNR, Duarte WR, Drummond JL, Yamauchi M. Application of crosslinkers to dentin collagen enhances the ultimate tensile strength. J Biomed Mater Res B Appl Biomater 2007; 80: 268-272.

15. Han B, Jaurequi J, Tang BW, Nimni ME. Proanthocyanidin: a natural crosslinking reagent for stabilizing collagen matrices. J Biomed Mater Res A 2003; 65: 118-124.

16. Ritter AV, Swift EJ, Yamauchi M. Effects of phosphoric acid and glutaraldehyde-HEMA on dentin collagen. Eur J Oral Sci 2001; 109: 348-353.

17. Buonocore MG. A simple method of increasing the adhesion of acrylic filling materials to enamel surfaces. J Dent Res 1955; 34: 849-853.

18. Nakabayashi N, Kojima K, Masuhara E. The promotion of adhesion by the infiltration of monomers into tooth substrates. J Biomed Mater Res A 1982; 16: 265-273.

19. Hashimoto M, Nagano F, Endo K, Ohno H. A review: biodegradation of resin-dentin bonds. Japan Dent Sci Rev 2011; 47: 5-12.

20. Carrilho M, Carvalho RM, Tay FR, Yiu C, Pashley DH Durability of resin-dentin bonds related to water and oil storage. Am J Dent 2005; 18: 315-319.

21. Sheu MT, Huang JC, Yeh GC, Ho HO. Characterization of collagen gel solutions and collagen matrices for cell culture. Biomaterials 2001; 22: 1713-1719.
22. Petite H, Rault I, Huc A, Menasche P, Herbage D. Use of the acyl azide method for cross-linking collagen-rich tissues such as pericardium. J Biomed Mater Res A 1990; 24 : 179-187.

23. William C. Treeseande Evans Pharmacoegnosy. CRC Press, London 2008; 8: 233-235.

24. Abdalla S, Pizzi A, Bahabri F, Ganash A. Analysis of Valonia oak (Quercus aegylops) acorn tannin and wood adhesives application. BioResources 2015; 10: 7165-7177.

25. Nagpal R, Singh P, Singh S, Tyagi SP. Proanthocyanidin: a natural dentin biomodifier in adhesive dentistry. J Restor Dent 2016; 4: p. 1.

26. Chang Y, Shin D. Effect of chlorhexidine application methods on microtensile bond strength to dentin in Class I cavities. Oper Dent 2010; 35: 618-623.

27. Umachigi S, Jayaveera KN, Ashok Kumar CK, Kumar GS, Vrushabendraswamy BM, Kishore Kumar DV. Studies on wound healing properties of Quercus infectoria. Trop J Pharm Res 2008; 7: 913-9.

28. Mapar M, Kalantari S. The comparison of effect of chlorhexidine and collagen cross linking agent (oak extract) on composite-dentine micro tensile bond strength. Dissertation. J AJUMS 2015; 1-30.

29. Salminen JP, Roslin T, Karonen M, Sinkkonen J, Pihlaja K, Pulkkinen P. Seasonal variation in the content of hydrolyzable tannins, flavonoid glycosides, and proanthocyanidins in oak leaves. J Chem Ecol 2004; 30: 1693-1711.

30. Castellan CS, Pereira PN, Grande RHM, Bedran-Russo AK. Mechanical characterization of proanthocyanidin-dentin matrix interaction. Dent Mater 2010; 26: 968-973.

31. Leitune VCB, Portella FF, Bohn PV, Collares FM, Samuel SMW. Influence of chlorhexidine application on longitudinal adhesive bond strength in deciduous teeth. Braz Oral Res 2011; 25: 388-392.

32. Loguercio AD, Stanislawczuk R, Polli LG, Costa JA, Michel MD, Reis A. Influence of chlorhexidine digluconate concentration and application time on resin-dentin bond strength durability. Eur J Oral Sci 2009; 117: 587-596.

33. Popović BM, Stajner D, Zdero R, Orlović S, Galić Z. Antioxidant characterization of oak extracts combining spectrophotometric assays and chemometrics. Sci World J 2013; 2013: 134656.

34. Liu Y, Chen M, Yao X, Xu C, Zhang Y, Wang Y. Enhancement in dentin collagen's biological stability after proanthocyanidins treatment in clinically relevant time periods. Dent Mater 2013; 29: 485-492.

35. Srinivasulu S, Vidhya S, Sujatha M, Mahalaxmi S. Shear bond strength of composite to deep dentin after treatment with two different collagen cross-linking agents at varying time intervals. Oper Dent 2012; 37: 485-491.

36. Leme-Kraus A, Aydin B, Vidal CMP, Phansalkar RM, Nam JW, McAlpine J, Pauli GF, Chen S, Bedran-Russo AK. Biostability of the proanthocyanidins-dentin complex and adhesion studies. J Dent Res 2017; 96: 406-412.

\section{Address for correspondence:}

\section{Faramarz Zakavi MD}

Department of Restorative Dentistry

School of Dentistry

Ahvaz Jundishapur University of Medical Sciences

Ahvaz, Iran

E-mail: faramarzzakavi@yahoo.com 